\title{
PENERAPAN MODEL TREFFINGER DENGAN MEDIA COLORCARD UNTUK MENINGKATKAN PRETASI BELAJAR MATERI OPERASI HITUNG BILANGAN PECAHAN
}

\author{
Djemari \\ SDN Tumpakrejo 05 Kecamatan Gedangan Kabupaten Malang \\ E-mail: djemari015@gmail.com
}

\section{Tersedia Online di}

http://www.jurnal.unublitar.ac.id/ index.php/briliant

\section{Sejarah Artikel}

Diterima pada 2 Januari 2017

Disetuji pada 20 Januari 2017

Dipublikasikan pada 1 Februari

2016 Hal. 1 -6

\section{Kata Kunci:}

model treffinger, media

colorcard, prestasi belajar,

operasi hitung

\begin{abstract}
Abstrak: Perkembangan globalisasi yang pesat menimbulkan banyak pengaruh untuk berbagai kalangan salah satunya adalah anak-anak usia SD. Sehingga pembelajaran untuk mengembangkan kognitif dan afektif sangat diperlukan untuk menyaring pengaruh globalisasi tersebut. Jadi, membelajarkan Matematika yang salah satu mata pelajaran dalam ranah kognitif dan memasukan ranah afektif pembelajaran. Dalam kenyataannya pembelajaran tersebut diperlukan untuk anak SD Kelas 6 di SDN Tumpakrejo 5. Sehingga, membelajarkan Matematika pada materi Operasi Hitung Bilangan Pecahan dengan memasukkan nilai afektif ke dalamnya menggunakan Model pembelajaran Treffinger dengan media Color Card. Pembelajaran ini memiliki tujuan meningkatkan prestasi belajar matematika siswa kelas 6 dengan menumbuhkan nilai afektif.
\end{abstract}

Banyaknya kompetensi dasar yang harus dikuasai oleh siswa dalam suatu jenjang terutama pada sekolah dasar akan memberikan tuntutan kepada siswa untuk terus belajar. Namun kenyataannya siswa merasa malas untuk mengikuti pembelajaran yang dirasa rumit seperti Matematika.

Hasil belajar merupakan salah satu cara mengetahui keberhasilan dari suatu pembelajaran. Namun rendahnya hasil belajar Matematika siswa kelas 6 juga disebabkan oleh beberapa factor antara lain: model, metode dan media pembelajaran yang diterapkan disekolah sudah biasa dilakukan, sehingga membosankan bagi siswa, pengelolaan kelas yang kurang efisien sehingga kebanyakan siswa sering ramai dan gaduh. Sehingga pemahaman terhadap Matematika sulit dicermati dan berakibat pada kemampuan siswa dalam pemecahan masalah. Tidak hanya itu siswa juga merasa takut meski hanya mendengarkan kata matematika.. Sebenarnya untuk menjadikan pembelajaran menjadi mudah dan membuat siswa menyukai dan merasa senang. Terdapat beberapa cara untuk memberikan inovasi di dalam suatu pembelajaran dengan cara mengganti model yang lebih menyenangkan, menggunakan media yang mampu mempermudah siswa dalam menguasai pembelajaran, mengelola kelas yang efisien atau dengan memberikan permainan.

Oleh karena itu, penulis memilih model pembelajaran yang sudah ada namun jarang dipakai yaitu model pembelajaran Treffinger.Menurut Treffinger (Huda, 2013), digagasnya model ini adalah karena perkembangan zaman yang 
terus berubah dengan cepat dan semakin kompleksnya permasalahan yang harus dihadapi. Oleh karena itu, untuk mengatasi permasalahan tersebut dapat dilakukan dengan cara memperhatikan fakta-fakta penting yang ada di lingkungan sekitar lalu memunculkan berbagai gagasan dan memilih solusi yang tepat untuk kemudian diimplementasikan secara nyata. Menurut penulis model pembelajaran Treffinger ini sesuai dengaan penggunaan media Color Card. Color Card merupakan kartu warna yang dapat dijadikan sebagai salah satu media pembelajaran yang efektif.

Tujuan penulis menuliskan pembelajaran dengan penerapan model treffinger dengan media colorcard untuk meningkatkan prestasi belajar materi operasi hitung bilangan pecahan, yaitu untuk menjawab dan menjelakan latar belakang artikel ini yaitu bagaimana penerapan model treffinger dengan media colorcard untuk meningkatkan prestasi belajar siswa kelas 6 SDN Tumpakrejo 05 materioperasi hitung bilangan pecahan.

\section{PEMBAHASAN}

Model Treffinger

Artikel ini akan membahas sebagian kecil tentang pembelajaran yang menerapkan model pembelajaran treffinger dengan media colorcard untuk meningkatkan prestasi belajar materi operasi hitung bilangan pecahan di kelas 6 SDN Tumpakrejo 05. Sebelum membahas tentang bagaimana menerapkan model treffinger akan dibahas apa itu model. Adapun Sukamto, dkk (dalamTrianto 2009:74) mengemukakan maksud dari Model pembelajaran adalah kerangka konseptual yang melukiskan prosedur yang sistematis dalam mengorganisasikan pengalaman belajar untuk mencapai tujuan belajar tertentu dan berfungsi sebagai pedoman bagi para perancang pembelajaran dan para pengajar dalam merencanakan aktivitas belajar mengajar.

Seperti halnya ungkap Dewey dalam Majid 2015: 13 bahwa model pembelajaran merupakan suatu rencana atau pola yang dapat kita gunakan untuk merancang tatap muka di kelas, atau pembelajaran tambahan di luar kelas dan untuk menajamkan materi pengajaran. Dalam hal ini dapat dikatakan bahwa model pembelajaran merupakan kerangka dasar pembelajaran yang dapat diisi oleh beragam muatan mata pelajaran sesuai dengan karakteristik kerangka dasarnya. Selain itu model pembelajaran dapat muncul dalam beragam bentuk variasinya sesuai dengan landasan filosofis dan pedagogis yang melatarbelakanginya.

Sudrajat (dalam lif dan sofan, 2014:57) berpendapat bahwa model pembelajaran merupakan bungkus atau bingkai dari penerapan suatu pendekatan, strategi, metode, teknik, dan taktik/ gaya pembelajaran. Dari beberapa pendapat diatas dapat ditarik kesimpulan yaitu model pembelajaran merupakan suatu rencana atau pola yang dirancang sehingga dapat digunakan sebagai kerangka dasar atau pedoman dalam merencanakan aktivitas belajar mengajar, merancang bahan, dan membimbing tindakan/ aksi pengajar dalam setting pembelajaran di kelasatau setting lainnya.

Model Treffinger merupakan revisi atas kerangka kerja CPS yang dikembangkan oleh Osborn. Menurut Treffinger dalam Huda (2013), digagasnya 
model ini adalah karena perkembangan zaman yang terus berubah dengan cepat dan semakin kompleksnya permasalahan yang harus dihadapi. Oleh karena itu, untuk mengatasi permasalahan tersebut dapat dilakukan dengan cara memperhatikan fakta-fakta penting yang ada di lingkungan sekitar lalu memunculakan berbaga gagasan dan memilih solusi yang tepat untuk kemudian diimplementasikan secara nyata. Treffinger dalam Huda (2013) menyebutkan bahwa model pembelajaran ini terdiri atas 3 komponen penting, yaitu Understanding Challenge (memahamitantangan), Generating Ideas (membangkitkangagasan), danPreparing for Action (mempersiapkantindakan).

Model pembelajaran kreatif treffinger termasuk dalam model osbornparne (Donald J. Treffinger dan Isaken). Model pembelajaran treffinger merupakan model pembelajaran yang menuntut peserta didik untuk berpikir kreatif dalam memecahkan masalah. Langkah-Langkah Model Treffing. Treffinger (1994) menyebutkan bahwa model pembelajarantreffinger terdiri atas tiga komponen penting, yaitu understandingchallenge, generating ideas, dan preparing for action, yang kemudiandirinci ke dalam enam tahapan sebagai berikut: (Miftahul Huda 318-319) (1) Understanding Challenge (memahami tantangan); a) Menentukan tujuan, yaitu guru menginformasikan kompetensi yang harus dicapai dalam pembelajaran.; b) Menggali data, guru mendemonstrasikan/ menyajikan fenomena alam yang dapat mengundang keingintahuan peserta didik.; c) Merumuskan masalah, guru memberi kesempatan kepada peserta didik untuk mengidentifikasi permasalahan.

(2) Generating ideas (membangkitkan gagasan); Tahapan Generating ideas, guru memberi waktu dan kesempatan pada peserta didik untuk mengungkapkan gagasan dan juga membimbing peserta didik untuk menyepakati alternatif pemecahan yang akan diuji.

(3) Preparing for action (mempersiapkan tindakan); a) Mengembangkan solusi, dalam tahapan ini guru mendorong peserta didik untuk mengumpulkan informasi yang sesuai, melaksanakan eksperimen untuk mendapatkan penjelasan dan pemecahan masalah;b) Membangun penerimaan, yaitu guru mengecek solusi yang telah diperoleh peserta didik dan memberikan permasalahan yang baru namun lebih kompleks agar peserta didik dapat menerapkan solusi yang telah diperoleh.

\section{Media Pembelajaran Color Card}

Menurut Heinich, dkk. (1993) dalamkutipan Riono Edi Santoso (2103) media merupakan perantara dari sumber pesan kepada penerima pesan. Secara harfiah media diartikan sebagai medium atau perantara. Dalam kaitannya dengan proses komunikasi dan pembelajaran, media diartikan sebagai wahana penyalur pesan pembalajaran. Media pengajaran diartikan sebagai segala sesuatu yang dapat digunakan untuk menyalurkan pesan (message), merangsang pikiran, perasaan, perhatian dan kemauan siswa sehingga dapat mendorong proses belajar.

Media pembelajaran Colorcard bisa juga berarti kartu warna . Menurut Susanto (2011:109) permainan flash card berdampak positif terhadap peningkatan kemampuan berhitung, karena permainan kartu ini dapat merangsang anak lebih cepat mengenal angka, membuat minat anak semakin menguat dalam menguasai 
konsep bilangan, serta merangsang kecerdasan dan ingatan anak. Kartu angka menurut Hurlock (1978) (dalam Susanto (2011:107-108) seiring dengan perkembangan pemahaman bilangan permulaan ini, menyatakan bahwa konsep yang dimulai dipahami anak diantaranya konsep bilangan.

Berdasarkan pendapat para ahli tentang kartu, maka dengan alat peraga color card ini diharapkan siswa dapat lebih mudah memahami materi operasi hitung bilangan bulat. Kartu termasuk dalam jenis alat peraga cetak.

Dalam artikel ini color card adalah kartu yang berisi materi dan soal dimana siswa mendiskusikan apa hubungannya materi tersebut dengan soal itu dengan kelompoknya.

\section{Langkah-langkah Model Treffinger Group dengan Media Color Card}

Adapun Langkah-langkah model treffinger group dengan media color card adalah (1) Understanding Challenge (memahami tantangan): a) Menentukan tujuan, yaitu guru menginformasikan kompetensi yang harus dicapai dalam pembelajaran.; b) Menggali data, guru menyediakan 4 warna Colorcardsetiap warna berjumlah 5-6 kartu yangberisi materi dan soal saling berkaitan. ; c) Merumuskan masalah, siswa yang mendapatkan Colorcard yang memiliki warna sama menjadi satu kelompok dan untuk mengidentifikasi permasalahan yang ada pada kartu tersebut.

(2) Generating ideas (membangkitkan gagasan): Tahapan Generating ideas, guru memberi waktu dan kesempatan pada peserta didik untuk mengungkapkan gagasan dan juga membimbing peserta didik untuk menyepakati alternatif pemecahan yang akan diuji.

(3) Preparing for action (mempersiapkan tindakan): a) Mengembangkan solusi, dalam tahapan ini guru mendorong peserta didik untuk mengumpulkan informasi yang sesuai untuk mendapatkan penjelasan dan pemecahan masalah.; b) Membangun penerimaan, yaitu guru mengecek solusi yang telah diperoleh peserta didik dan memberikan permasalahan yang baru namun lebih kompleks agar peserta didik dapat menerapkan solusi yang telah diperoleh.

\section{Kelebihan Model Treffinger}

Kelebihan model pembelajaran treffinger antara lain sebagai berikut: (1) Mengasumsikan bahwa kreativitas adalah proses dan hasil belajar. Kreativitas dianggap sebagai proses dan hasil belajar karena kreativitas merupakan suatu kemampuan untuk menciptakan hal baru, membangun ide-ide baru dengan mengkombinasikan, mengubah, menerapkan ulang ide-ide yang sudah ada.

(2) Dilaksanakan kepada semua peserta didik dalam berbagai latar belakang dan tingkat kemampuan. Pembelajaran treffinger mengutamakan proses dan pengalamanbelajar dalam pemecahan masalah.(3) Mengintegrasikan dimensi kognitif dan afektif. Model pembelajaran treffinger melibatkan kemampuan kognitif maupun afektif peserta didik dalam memecahkan masalah,

(4) Melibatkan secara bertahap kemampuan berpikir konvergen dan divergen dalam proses pemecahan masalah, 5) Memiliki tahapan pengembangan yang sistematik, dengan beragam metode dan teknik untuk setiap tahap yang 
dapat diterapkan secara fleksibel. Model pembelajaran treffinger dikembangkan dari beragam metode pembelajaran seperti demonstrasi, diskusi dan eksperimen.

\section{Kekurangan Model Pembelajaran Treffinger}

Model pembelajaran treffinger memilikikekurangan. Kekurangan model pembelajaran treffinger antara lain(Miftahul Huda:320-321): (1) Membutuhkan waktu yang lama, (2) Perbedaan level pemahaman peserta didik dalam menanggapi masalah, (3) Model pembelajaran ini tidak cocok untuk diterapkan pada peserta didik tingkatan taman kanak-kanak dan kelas-kelas awal sekolah dasar.

\section{KESIMPULAN}

Tulisan ini dapat disimpulkan bahwa pembelajaran matematika materi operasi hitung bilangan pecahan dapat diajarkan dengan menerapkan model Treffinger menggunakan media Colorcard. Pembelajaran menggunakanmodel Treffinger dan media Colorcard akan menumbuhkan kreatifitas berfikir siswa dalam masyarakat belajar dengan cara yang menyenangkan. Karenatujuan dari pembelajaran ini adalah untuk menyeimbangkan keterampilan kognitif seperti mempermudahkan siswa dalam memahami materi, meningkatkan hasil belajar siswa dan keterampilan afektif yaitu melatih kemampuan siswa untuk berani di kelas, menanamkan tanggungjawab dan rasa toleransi pada sesama.

\section{SARAN}

Bagi guru dapat menggunakan model beserta media ini sebagai alternatif penyampaian materi pelajaran yang dikemas menarik sehingga dapat meningkatkan prestasi belajar siswa. Diharapkan guru dapat lebih berinovasi dalam penyampaian materi terutama pada mata pelajaran Bahasa Jawa.

Bagi siswa yaitu siswa dapat: (1) memanfaatkan sumber media belajar secara optimal untuk lebih memahami materi, (2) Selalu minta bimbingan kepada guru jika mengalami kesulitan dalam belajar. (3) Selalu aktif berkomunikasi baik dengan guru maupun dengan teman untuk memecahkan suatu masalah.

Untuk sekolah yaitu (1) Meningkatkan pembinaan terhadap guru serta memberi motivasi kepada guru dalam melaksanakan tugasnya sebagai pendidik, Memberikan dukungan dan penghargaan terhadap segala usaha guru dalam rangka menciptakan pembelajaran yang aktif, efektif, kreatif, dan menyenangkan.

\section{DAFTAR RUJUKAN}

Ahmadi, Iif Khoiru dan Sofan, Amri. 2014. Pengembangan \& Model Pembelajaran Tematik Integratif. Jakarta: Prestasi Pustaka.

B.Uno, Hamzah. 2007. Model-Model Pembelajaran Menciptakan Proses Belajar Mengajar Yang Kreatif dan Efektif. Jakarta: PT Bumi Aksara.

B.Uno, Hamzah dan Muhammad, Nurdin. 2013. Belajar dengan Pendekatan Paikem: Aktif, Inovatif, Lingkungan, Kreatif, Efektif, Menarik. Jakarta: PT Bumi Aksara. 
Huda, Miftahul. 2013. Model-model pengajaran dan pembelajaran. Pustaka Pelajar

Treffinger, Donald J. dan Isaken. 2005. Creative Problem Solving: The History, Development,and Implications for Gifted Education and Talent Development. Gifted Child Quarterly. 49(4): 343.

Joyce, Bruce dan Marsha Weil. 1986. Models of Teaching. Third Edition. New Jersey: Prentice-Hall Inc

Majid, Abdul. 2015. Strategi Pembelajaran. Bandung : PT Remaja Rosdakarya

Trianto. 2009. Mengembangkan Model Pembelajaran Tematik. Jakarta: Prestasi Pustaka. 